\title{
COVID-19: МУЛЬТИДИСЦИПЛІНАРНІ ДОСЛІДЖЕННЯ СУДОВО- ФАРМАЦЕВТИЧНИХ РИЗИКІВ ТА ПРИЧИННО-НАСЛІДКОВИХ ЗВ’ЗКІВ НЕКВАЛІФІКОВАНОЇ МЕДИЧНОЇ ДОПОМОГИ ПАЦІЕНТАМ ПІД ЧАС ПАНДЕМІї
}

\section{COVID-19: MULTIDISCIPLINARY RESEARCHES OF FORENSIC AND PHARMACEUTICAL RISKS AND CAUSAL RELATIONSHIPS OF UNQUALIFIED MEDICAL CARE FOR PATIENTS DURING PANDEMIC}

Iгор Гайдучок (Ihor Hayduchok, Doctor of Medical Sciences) ${ }^{1}$, Валерій Шаповалов (Valerii Shapovalov, Doctor of Pharmaceutical Sciences, Professor) $)^{1,2,3}$

1 ТзОВ «Львівський медичний інститут», Львів, Україна (Lviv Medical Institute LLC, Lviv, Ukraine)

2 Національна асоціація адвокатів України, Київ, Україна (Ukrainian National Bar Association, Kyiv, Ukraine)

3 Адвокатське об’сднання «Апофеоз», Харків, Україна (Advocates Company "Apotheosis", Kharkiv, Ukraine)

${ }^{*}$ Corresponding author: Ihor Hayduchok
Received: January 03, 2022

Published: January 20, 2022
Abstract. A multidisciplinary study was conducted to study the forensic and pharmaceutical risks and to establish the casual relationships of unqualified medical care (medical errors) to patients and the development of diseases during the COVID-19 pandemic. It was substantiated that in the context of the coronavirus

pandemic, multidisciplinary research in the field of healthcare combines interdisciplinary links of scientists from around the world in medicine, pharmacy, law, economics on good medical practice, pharmaceutical provision and availability of clinical and pharmacological, nomenclature and legal groups for all contingents of patients. It was noted in examples from forensic and pharmaceutical practice that unqualified medical care (medical or medical errors) can lead to varying degrees of severity of health disorders, improper performance of professional duties by a medical or pharmaceutical worker contains in its content forensic pharmaceutical risks provision of medicines, ultimately leads to health offenses. Causation has been shown to be associated with pandemics of coronavirus infection in the context of COVID, long-COVID and post-COVID health disorders. It was noted that the pandemic to COVID-19 and its consequences have three characteristic features of traumatic events: unpredictability, uncontrollability, threat of death or serious injury. The experience of the USA, France, Israel, China, EU countries on the example of Estonia on the organization of the healthcare system during the COVID19 pandemic were studied. It was shown that the commercialization of the system of legal relations "doctor-patientpharmacist-lawyer" affects the quality 
of medical practice and the availability of medicines for patients. Emphasis was placed on the continuing of professional development for healthcare professionals in the casual relationship of unqualified medical care (medical errors) to patients and the development of COVID, long-COVID and postCOVID diseases during the COVID-19 pandemic. The prospects of using
Estonia's experience in the digital healthcare system, which covers all medical institutions in the country and every citizen were mentioned.

Keywords: multidisciplinary research, forensic and pharmaceutical risks, causation, unqualified medical care, medical errors, COVID-19 pandemic, long-COVID, post-COVID, Estonian digital health care system.

Вступ. В умовах пандемії коронавірусної хвороби мультидисциплінарні дослідження у сфері охорони здоров'я об'єднують міждисциплінарні зв'язки вчених усього світу з медицини, фармації, права, економіки щодо належної медичної практики, фармацевтичного забезпечення та доступності лікарських засобів клініко-фармакологічних, класифікаційно-правових та номенклатурноправових груп для всіх контингентів пацієнтів [1-5]. Судово-фармацевтичні ризики виникають упродовж надання медичної допомоги, обігу лікарських засобів на рівні закладів охорони здоров'я (лікарні, аптеки, поліклініки), фармакотерапії супроводу розладів здоров'я, доступності для пацієнтів ліків всіх клініко-фармакологічних, класифікаційно-правових та номенклатурно-правових груп [6-9].

Причинно-наслідкові зв'язки було досліджено при формуванні, розвитку та розповсюдженні адиктивних та коморбідних розладів здоров'я та незаконного обігу психоактивних речовин різних класифікаційно-правових груп. Причиннонаслідкові зв'язки прослідковуються в умовах пандемії коронавірусної інфекції на тлі ковідних, лонгковідних та постковідних розладах здоров'я [10-12]. Некваліфікована медична допомога може приводити до різного ступеню тяжкості розладів здоров'я, неналежне виконання професійних обов'язків медичним або фармацевтичним працівником містить у своєму змісті судовофармацевтичні ризики щодо неналежного забезпечення лікарськими засобами, у кінцевому результаті приводить до правопорушень у сфері охорони здоров'я [13$16]$.

Лікарські помилки при здійсненні обігу лікарських засобів на етапі їх призначення, виписки, дозування, режиму фармакотерапії вивчалися в рамках судової фармації раніше. На жаль, в останній час все частіше з'являються публікації в Україні, США, Великобританії та країнах Європейського Союзу про те, що лікарі різних номенклатурних спеціальностей (стоматологи, хірурги, психіатри, гінекологи та інш.) в ланцюзі правовідносин «лікар-пацієнт-провізор» порушують правила обігу медикаментів та скоюють лікарські помилки. Такі лікарські помилки становлять судово-фармацевтичні ризики у причиннонаслідкових зв'язках некваліфікованої медичної допомоги, що підтверджуються під час судово-медичних, судово-наркологічних, судово-криміналістичних та інш. експертних досліджень, та які мають ознаки проступку - кримінального злочину, передбаченого статтями 140, 321-324 та інш. Кримінального Кодексу 
(KК) України [17-22]. Разом з тим в умовах пандемії на COVID-19 важливим моментом $\epsilon$ те, що платформою для попередження розповсюдження цього небезпечного захворювання виступає щеплення вакцинами, які знаходяться в обігу в закладах охорони здоров'я України [23]. Так, за даними МО3 України (за добу 30.10.2021) в Україні зафіксовано 17430 нових підтверджених випадків коронавірусної хвороби COVID-19 (з них дітей - 1108, медпрацівників - 178). За час вакцинації (з 24.02.2021) від COVID-19 проведено усього 17577773 щеплення серед населення, при цьому 94\% госпіталізованих громадян із COVID19 - невакциновані [24].

За прогнозами Міністра охорони здоров'я України В. Ляшко - нова хвиля захворювання на COVID-19 серед всіх верств населення, може прийти до держави вже наприкінці січня 2022 р., якщо не втрутяться нові мутації і цього не станеться ще раніше [25]. Проте ми сподіваємося, що [26]: летальних випадків під час четвертої хвилі буде менше, якщо громадяни масово підуть вакцинуватися; громадяни не будуть егоїстами і не вимагатимуть від лікарів, які працюють у складних умовах пандемії, бустерної дози вже зараз, коли перше щеплення в Україні не зробили більшості людей; ревакцинація щодо щеплення 3-ю дозою буде доступна до громадян в січня 2022 р.

На наш погляд, фахівцям, які працюють у МО3 України, необхідно вивчати досвід протидії пандемії у сфері охорони здоров'я системами США, Франції, Ізраїлю, Китаю та інш. країн [27-32]. На думку Anthony Fauci [33], новий штам COVID-19 «омікрон» зараз є як мінімум у 10 штатах США (Нью-Джерсі, Пенсільванія, Міссурі, Меріленд, Небраска та інш.). Існує «абсолютне» поширення серед населення і в найближчі дні число випадків захворювання на COVID-19 тільки зростатиме. Тому, фахівці сфери охорони здоров'я США вже вирішили про необхідність робити ревакцинацію усьому дорослому населенню (починаючи 3 18-річного віку і старше), що отримали хоча би вакцину PfizerBioNTech або Moderna, через шість місяців після другої дози. Разом с тим, адміністративні органи СС з квітня 2021 р. обговорювали та пропонували можливість прискорити бустерне щеплення населення, але при цьому рекомендовано те, що важливо розрізняти додаткову дозу для людей 3 ослабленою імунною системою та бустерні дози для громадян 3 нормальною імунною системою. Так, наприклад, у Франції, офіційна влада наголошує на тому, що бустерне щеплення доступно всім громадянам віком старше 18 років, через 5 місяців після отримання другої дози, тобто, - до середини січня 2022 р. У літніх людей є час до середини грудня 2021 р., щоб отримати ревакцинацію, інакше громадяни ризикують втратити свою санітарну перепустку (французький паспорт щодо COVID-19) [27-33].

Тим часом лікарі в Ізраїлі організували процес таким чином, що третьою дозою щеплено вже понад 40\% громадян [34]. Дослідження, що опубліковано в журналі Lancet [35], також показує, що ревакцинація щодо щеплення 3-е дозою на $81 \%$ ефективніше у запобіганні смерті порівняно з тими, хто робив лише 2 ін'єкції як мінімум 5 місяців потому. Відмічено, що у багатьох країнах спостерігається відродження інфекцій SARS-CoV-2, незважаючи на досі успішні 
кампанії вакцинації, причиною яких, як вважається, є більш висока заразність «Дельта-варіанту» та зниження імунітету після більш ранньої вакцинації. Незалежно від причини, ці ранні результати показують, що третя доза мРНКвакцини ефективна для зниження важких результатів, пов'язаних з COVID-19, для пацієнтів, які отримали дві дози як мінімум за 5 місяців до цього.

Водночас, як зазначає Gabi Barbash [36], в Ізраїлі знову потрібно ввести обов'язкові маски для громадян не лише у закритих приміщеннях, а й на відкритому повітрі. При цьому наголосив на наступних заходах, а саме: важливість запровадження більш суворих перевірок під час прибуття людей із інших країн до міжнародного аеропорту Бен-Гуріон; запровадити суворі покарання для осіб, у яких буде встановлено підроблене свідоцтво про вакцинацію або імунітет; вимагати від тих, хто контактував 3 підтвердженими випадками захворювання, запровадити карантин, навіть якщо громадянин повністю вакциновано, тому що половина з тих, хто нині перебуває у тяжкому стані у лікарнях країни, отримали обидві дози вакцини.

За даними вчених, нове коронавірусне захворювання (COVID-19) вперше у світі спалахнуло в Китаї (Ухань, грудень 2019 р.), коли китайський уряд зіткнувшись із цим невідомим інфекційним захворюванням, негайно вжив таких превентивних заходів [37-40]:

1 - запровадження загальнонаціонального карантину;

2 - надання медичної підтримки та виявлення контактних осіб з хворими;

3 - мобілізацію ресурсів з усієї країни;

4 - посилення освіти населення (Інтернет, телебачення, радіо та ін.);

5 - посилення індивідуального захисту кожного громадянина (маски, рукавички, дезінфекція та ін.);

6 - медична ізоляція конкретного хворого;

7 - контроль мобільності населення та скорочення зборів;

8 - розгляд та прийняття законів, нормативно-правових актів (наприклад, Закон «Про судове переслідування за злочини, пов'язані 3 порушенням заходів профілактики пневмонії, інфікованої новим коронавірусом»);

9 - посилення міжнародного співробітництва.

Пандемія на COVID-19 та іiі наслідки мають три характерні характеристики травмуючих подій [41]: непередбачуваність, неконтрольованість, загроза смерті або серйозної травми за МКБ-11 (Міжнародна класифікація хвороб) та DSM-5 (Діагностичні та статистичні дані). Пацієнти з COVID-19, як правило, зазнавали високого ризику психічних та соціальних проблем зі здоров'ям. Хоча епідемія, очевидно, вплинула на їхній загальний стан здоров'я, що призвело до негативних емоцій чи побоювань, вона також мала позитивний ефект, наприклад, більш позитивний погляд на свої стосунки з сім'ями чи іншими людьми та появу більшої кількості думок та поглядів на життя. Дослідження спонукало медичний персонал не поспішати, вислуховуючи пацієнтів, та приділяти більше уваги конкретним психологічним та соціальним проблемам зі здоров'ям у майбутньому лікуванні. 
Технічний документ Агентства охорони здоров'я ООН для держав-членів став найсерйознішим застереженням ВООЗ про новий штам коронавірусу, виявлений у Південній Африці. Агентство повідомило, що попередні докази підвищують ймовірність того, що «безпрецедентна кількість «спайкових мутацій» може підвищити здатність штаму поширюватися серед населення [42]. Органи охорони здоров’я в деяких країнах (Велика Британія, Німеччина, Італія, Бельгія, Ізраїль, Іспанія, Нідерланди, Португалія, Швеція, Шотландія, Австрія, Канада, Данія, Гонконг) вже виявили новий штам «омікрон» та посилили карантинні заходи [43]. Існують великі ризики щодо потрапляння цього штаму до України саме через мандрівників, що повертаються з країн СС, Канади і США.

За даними судово-фармацевтичної практики, у сфері охорони здоров’я виявляються факти із шахрайства, що пов'язані із службовим злочинами та підробкою документів, які офіційно видаються закладами охорони здоров'я [44]. Завдяки спецопераціям, що проводять співробітники Національної поліції України, Служби Безпеки України та Генеральної прокуратури України, виявляються факти, як шахраї i доброчесні медичні працівники, які використовують бланки і печатки закладу охорони здоров'я, i видають підроблені документи окремим громадянам за винагороду. I там, де документуються i виявляються факти злочинної діяльності, відразу відкриваються кримінальні провадження, а лікарі відсторонюються від роботи або звільняються від виконання професійних обов'язків.

Низький рівень щеплення серед населення України, фальсифікація документів, що видають заклади охорони здоров'я про щеплення, введення неправдивих даних про щеплення в електронну базу, виявлення в червоній зоні стаціонару хворих, які знаходяться на IВЛ, що вони ввели в оману медичний персонал, мають фальшиві документи про вакцинацію, підвищують рівень лікарських помилок, а як наслідок - летальних випадків серед працездатної частини громадян, молоді, населення віком 60+ та дітей, що може привести до нової більш смертельної хвилі на COVID-19. Так, Всесвітня організація охорони здоров’я (ВООЗ) 29.11.2021 р. [45] попередила всі країни, що новий виявлений штам коронавірусу «омікрон» несе дуже високий загальний глобальний ризик сплесків інфекції з тяжкими наслідками.

В сучасних умовах, як зазначає Вороненко Ю. В., саме лікарі та провізори України продовжують працювати у дуже складних умовах [46] пандемії коронавірусної хвороби, яка суттєво впливає на якість та попит освітніх послуг. Особливо це стосується тих форм навчання, де основну роль грають медичні практичні навички: інтернатура, спеціалізація, стажування, майстер-класи, симуляційні тренінги. Але жорсткі карантинні протиепідемічні заходи - це сьогодні не єдина проблема, яка заважає ефективно працювати і розвиватися медичній та фармацевтичній освіті, тобто $є$ ще три виклики, які одночасно негативно протидіють дійсно самовідданій освітянській праці. По-перше, значне скорочення державного фінансування і відповідно критичне скорочення безперервного професійного розвитку (БПР) лікарів та провізорів. Держава практично десятиліттями не фінансує витрати закладів освіти на обладнання, 
комп'ютерні та симуляційні технології, публікації у міжнародних журналах, видання підручників, монографій, підтримку інфраструктури закладів вищої освіти (ЗВО), реактиви та витратні матеріали, міжнародні навчальні контакти. Навіть на державний іспит «Крок-3» за державним замовленням не виділяються кошти. По-друге, настав майже хаос у БПР, що пов'язано з тим, що лікарі та провізори мають легкі можливості набрати необхідні для атестації бали у чисельних «неакредитованих провайдерів», замість якісних освітніх послуг професіоналів. Можна просто купити собі необхідний сертифікат на якомусь так званому «семінарі». По-трете, залишилося ще багато принципових проблем у правовідносинах «клінічних кафедр і їх баз - комунальних неприбуткових підприємств (КНП)». Крім того, роль клініцистів у наданні медичної допомоги зведена нанівець. Навіть зникає юридичний дозвіл клінічній кафедрі навчати медицині у лікарні - КНП. Тому, метою роботи стало мультидисциплінарне дослідження щодо вивчення судово-фармацевтичних ризиків та встановлення причинно-наслідкових зв'язків некваліфікованої медичної допомоги (лікарських помилок) пацієнтам та розвитку захворювань під час пандемії COVID-19.

Матеріали та методи. Інформаційно-аналітичну основу дослідження склали праці з 19 дисциплін, що мають міждисциплінарні зв'язки: медичне право, фармацевтичне право, судова фармація, доказова фармація, клінічна фармація, медицина, організація охорони здоров'я, доказова медицина, судова медицина, криміналістика, інфекційні хвороби, іммунологія, внутрішні хвороби, фармація, промислова фармація, організація та управління фармацією, кримінальне право, адміністративне право, економіка. Зазначимо, що огляд наукових джерел літератури [47-77] було проведено із врахуванням рекомендацій Кокрейнівського товариства за PICO: P (population) - населення, що страждає на розлади здоров'я; I (intervention) - медицина, фармація, фармакотерапія, ефективні, безпечні, доступні ліки; C (comparator) - технологія дослідження; O (outcomes) - результати дослідження. В якості методів дослідження використано нормативно-правовий, документальний, ретроспективний, порівняльний, системний, табличний, судовофармацевтичний та графічний. Для обробки результатів, визначення узгодженості між досліджуваними параметрами використано програму Microsoft Excel 2010 (описові характеристики: мінімальне та максимальне значення, середнє значення).

Дослідження статті $є$ фрагментом науково-дослідних робіт ТзОВ «Львівський медичний інститут» за темою «Удосконалення системи обігу ліків під час фармакотерапії на засадах доказової і судової фармації, організації, технології, біофармації та фармацевтичного права» (номер державної реєстрації 0120U105348, термін виконання 2021-2026), Харківської медичної академії післядипломної освіти за темами «Удосконалення організаційно-правової процедури забезпечення ліками пацієнтів з позиції судової фармації, організації і управління фармацією» (номер державної реєстрації 0116U003137, термін виконання 2016-2020рр.) та «Фармацевтичне та медичне право: інтегровані підходи до системи обігу ліків 3 позиції судової фармації та організації 
фармацевтичної справи» (номер державної реєстрації 0121 U000031, термін виконання 2021-2026 pp.).

Результати та їх обговорення. Дотепер мультидисциплінарних судовофармацевтичних, судово-медичних і судово-психіатричних досліджень щодо встановлення причинно-наслідкових зав'язків відмови від щеплення, надання неправдивої інформації лікарю, причинення тілесних ушкоджень різного ступеня тяжкості під час надання стоматологічної та іншої медикофармацевтичної допомоги, лікарських помилок, встановлення зв'язків розвитку ковідних, лонгковідних та постковідних супутніх захворювань, в т.ч. і пов'язаних з системними аутоімунними хворобами, їх багатолитість і тактика ведення під час пандемії «COVID-19» не проводилося [77-88]. Лікарські помилки на тлі фармакотерапії хворих на «COVID-19» можуть бути пов'язані із тим, що пацієнти, які знаходяться на стаціонарному лікуванні у тяжкому стані, своєчасно не пройшли щеплення, або купували у злодіїв фальшиві довідки закладів охорони здоров'я про «щеплення», або «ПЦР-тести». Як відмічає Ірина Венедіктова [89], половина із майже 800 кримінальних проваджень, що порушено у 2021 р. цієї категорії стосуються саме махінацій з документами про щеплення від «COVID-19», 3 яких 104 громадянам (серед фігурантів кримінальних справ - шахраї, медики, працівники лабораторій, аптек, туристичних фірм та інш.). вже повідомили про підозру у підробці результатів тестів та документів про вакцинацію, а 88 обвинувальних актів спрямували до суду. Вивчення досвіду США довело, що медична (лікарська) помилка є третьою за значимістю причиною смерті після раку та хвороби серця [90]. Лікарські помилки у США щомісяця вбивають майже стільки ж людей, скільки COVID-19, якщо не проводити щеплення. Серед медичних працівників встановлено причини, що призводять до шкідливих наслідків [91]: промахи скальпеля; змішування результатів лабораторних досліджень; неправильне прийняття рішень; недостатня професійна підготовка; не дотримання чи ігнорування встановлених правил техніки безпеки; нерозуміння; збоїв обладнання та багато іншого; не дотримання гігієни рук (не завжди дезінфікують руки між прийомами пацієнтів, тим самим розповсюджуючи інфекцію); неправильного копіювання, невиконання чи втрати приписів лікарів; часте відволікання медперсоналом фармацевтів через проблеми, пов'язані 3 обігом ЛЗ (зникнення ліків, фальсифікація ліків); відмова пацієнтів оплачувати лікування хвороб, придбаних у лікарні.

Медична (лікарська) помилка визначається як ненавмисна дія (бездіяльність або вчинена дія), або дія, яка не призводить до наміченого результату, невиконання запланованої дії відповідно до призначення (помилка виконання), використання неправильного плану досягнення мети (помилка планування) або відхилення від процесу надання допомоги, яке може заподіяти або заподіяла шкоду пацієнту [92]. Шкода пацієнту від лікарської помилки може бути завдана на індивідуальному або системному рівні. Таксономія помилок розширюється, щоб краще класифікувати запобіжні фактори та події. На прикладі лікарських помилок приведемо прикладі із судово-фармацевтичної 
практики лікарів-стоматологів. Сьогодні лікарі-стоматологи повинні виконувати постанову МОЗ України від 09.05.2020 №19 [93].

Приклад 1. Дізнавач Рівненського районного управління НП України у Рівненській області закінчив досудове розслідування та скерував до суду матеріали кримінального провадження за ч. 1 ст. 125, ч. 1 ст. 126, ч. 2 ст. 140 Кримінального Кодексу України [94]. Під час досудового слідства було встановлено, що після візиту до приватного стоматолога у восьмирічної доньки мати виявила гнійну рану губи, тілесні ушкодження у вигляді осадження передньої поверхні шиї, крововиливи на передніх поверхнях лівого і правого плечей в середніх третинах, які відповідно до висновку експерта відносяться до легких тілесних ушкоджень [95]. Крім того, впродовж подальших трьох днів до поліції надійшло ще три звернення від батьків щодо побоїв та тілесних ушкоджень, спричинених дитячою лікаркою під час лікування зубів. Справу відкрили за частиною 2 статті 140 ККУ (Неналежне виконання професійних обов'язків медичним або фармацевтичним працівником). Зазначається, що раніше жінку вже звільняли з іншої клініки, зокрема й через скарги з боку кліснтів. Також до поліції звернулася 36-річна жителька Костополя, яка повідомила, що під час лікування зубів лікарка нанесла травми іiї 5-річній дитині. У цьому разі відкрили справу за ч.1 ст. 125 ККУ (Умисне легке тілесне ушкодження) [96].

Приклад 2. До поліції надійшло повідомлення про те, що до лікарні без свідомості доставлено 62-річну мешканку м. Житомир, директорку стоматологічного центру 3 численними тяжкими ушкодженнями голови та ножицями в правому оці [97]. Зазначається, що правоохоронці затримали 28річного місцевого жителя, робітника вказаного стоматологічного центру. Зловмисник заздалегідь спланував вбивство керівниці через борг. На цей час йому повідомлено про підозру, вирішується питання щодо обрання міри запобіжного заходу - тримання під вартою [98].

Приклад 3. Відкрито кримінальне провадження у 2017 р. у Маріуполі щодо смерті на прийомі у стоматолога 2-х річного хлопчика. Причиною смерті, як засвідчило розтин, стала неправильно встановлена інтубаційна трубка i, як наслідок, попадання марлевого тампону в дихальні шляхи дитини, що призвело до задухи [99].

Приклад 4. У Головному управлінні національної поліції Закарпаття зазначають, що було затримано мешканця села Страбичово Мукачівського району, 1983 року народження, який працював лікарем-стоматологом [100]. Лікар-стоматолог у себе вдома реалізовував за 2 тисячі грн фасовки по 2 грами метамфетаміну. Правоохоронці провели у лікаря дома обшук, під час якого виявили 2 тисячі грн, два згортки і пакет, в яких загалом було близько 7 грамів білої порошкоподібної речовини та ювелірні ваги з ії залишками. Речові докази було відправлено на експертизу. Стоматолога затримано в порядку ст. 208 КПК України. Разом з тим, у прокуратурі додають, що раніше правоохоронцями було задокументовано факт збуту підозрюваним лікарем-стоматологом 1,2 грами речовини з вмістом метамфетаміну за 1800 грн. Продавав лікар психотропні 
речовини у запаяному фрагменті медичного шприца. Прокуратура Закарпатської області лікарю-стоматологу оголосила підозру у вчиненні злочину, передбаченого ч. 1 ст. 307 КК України (незаконний збут психотропних речовин) [101].

Приклад 5. Пацієнтка-інвалід померла після того, як дантист у трастовій компанії NHS видалив їй усі зуби через тяжкий карієс. Пацієнтка знепритомніла через кілька годин після того, як іiі виписали, кілька днів провела на апараті життєзабезпечення в лікарні та померла [102].

Судово-фармацевтичний аналіз свідчить, що тенденція лікарських помилок зростає. В літературі можемо знайти численні приклади лікарських помилок. Описано про порушення режиму дозування для 16-річної пацієнтки антибіотиком кліндаміцином [103], коли замість введення 600 мг препарату упродовж 15 хвилин, кліндаміцин ввели у дозі 900 мг упродовж 1-2 хвилин. Описано про непритомність пацієнтки Ф. під час вечірки. Спроби серцеволегеневої реанімації виявилися безуспішними. Причиною смерті було визначено ядуху від аспірації вмісту шлунку через пригнічення блювотного рефлексу. Пацієнтка задихнулася, коли вміст їі шлунку потрапив у легені. Зазвичай блювотний рефлекс виштовхує викинутий матеріал. Однак у разі пацієнтки Ф. був пригнічений блювотний рефлекс. Експертне дослідження виявило наявність препаратів, похідних барбітурової кислоти (амобарбітал, секобарбітал). Пацієнтка Ф. приймала виписані раніше лікарем бірбітітурати, котрі й стали причиною пригнічення блювотного рефлексу [103]. Описано, що пацієнт Д. прибув до лікарні у справах ветеранів, штат Оклахома, зі скаргою на сильний біль у животі. Черговий лікар оглянув пацієнта Д., а потім прооперував його «для усунення перфорації у проксимальному відділі дванадцятипалої кишки, що призвела до дифузного перитоніту». Пацієнт Д. залишався у відділенні інтенсивної терапії протягом наступних 8 днів та помер. Причиною смерті стало порушення режиму дозування препарату Лазикс при внутрішньовенному введенні упродовж 8 днів [103].

Наступне завдання роботи було вивчення судово-фармацевтичних ризиків та встановлення причинно-наслідкових зв’язків некваліфікованої медичної допомоги (лікарських помилок) пацієнтам із аутоімунними хворобами та розвитком ковідних, лонгковідних та постковідних захворювань під час пандемії COVID-19. Як зазначає Wang L., Wang F., Gershwin M. [104], єдиної класифікації аутоімунних хвороб не існує, їх поділяють на органоспецифічні, що виникають в імунновідокремлених органах (щитоподібна залоза - тиреоїдит, око офтальмія, нервова система - розсіяний склероз, надниркові залози - ідіопатична Аддісонова хвороба, яєчники - асперматогенія та інші) й органонеспецифічні (сполучна тканина - ревматоїдний артрит, системний вовчак червоний, дерматоміозит, склеродермія, вузликовий періартеріїт; кров - ідіопатична тромбоцитопенічна пурпура, автоімунна гемолітична анемія; кишківник целіакія, Крона хвороба тощо). За патогенезом аутоімунні захворювання поділяють на хвороби 3 підтвердженим (гемолітична анемія, імунна тромбоцитопенія, тиреоїдит Хашимото, гіпертиреоз, цукровий діабет I та II 
ступенів, неплідність, симпатична офтальмія, перніціозна анемія, аутоімунний гепатит, системний червоний вовчак, ревматоїдний артрит та інш.), а також ймовірним (первинний біліарний цироз, синдром Шегрена, вузликовий періартеріїт то що) імунним патогенезом. Існують дві основні області, в яких імунна система призводить до патології: по-перше, синдроми імунодефіциту, при яких нездатність одного або декількох компонентів імунної системи відповідати захисним чином на патоген, і по-друге, системні аутоімунні хвороби [105]. Нездатність відрізнити себе від чужого часто називається порушенням толерантності та є основою аутоімунного захворювання.

За останні 10 років спостерігається помітне зростання кримінальних проваджень внаслідок встановлення причинно-наслідкових зв'язків некваліфікованої медичної допомоги (лікарських помилок) пацієнтам. За кордоном 32010 р. розвивається судова стоматологія (судова дентологія) [106]. Лікарі-стоматологи повинні знати, що існують спеціальні інструкції для пацієнтів зі СНІДом/ВІЛ та захворюваннями, що передаються статевим шляхом. При роботі 3 такими пацієнтами необхідно дотримуватися суворої конфіденційності. Розкриття персональної інформації може призвести до скарг за серйозне порушення професійної етики [107].

Дані країн СС показують, що медичні (лікарські) помилки відбуваються у 8-12\% госпіталізацій. Наприклад, Велика Британія за 2000 р. оцінила близько 850000 небажаних явищ (10\% госпіталізацій). Іспанія, Франція та Данія: хвороби внаслідок медичних помилок вражають приблизно 1 iз 20 пацієнтів в стаціонарі щорічно. Найбільш поширені 4 типи хвороб через лікарські помилки: інфекції сечовивідних шляхів (27\%); інфекції нижніх дихальних шляхів (24\%); хірургічні втручання, локальні інфекції (17\%) та інфекції кровотоку (10,5\%). Золотистий стафілокок виділяється приблизно в 5\% всіх інфекцій, пов'язаних 3 наданням некваліфікованої медичної допомоги. Пацієнти-жертви медичних помилок стверджують, що у 23\% випадків на них безпосередньо вплинула лікарська помилка; 18\% стверджують, що зазнали серйозної медичної помилки в лікарні; а $11 \%$ - що їм прописали неправильні ліки. Дані про лікарські помилки показують, що від 50\% до 70,2\% такої шкоди можна запобігти комплексним систематичним підходом до безпеки пацієнтів. Статистичні дані показують, що стратегії зниження частоти небажаних явищ тільки в СС можуть призвести до запобігання більше 750000 шкідливих медичних помилок на рік, що, у свою чергу, призведе до скорочення госпіталізації більш ніж на 3,2 мільйона днів; скорочення кількості інцидентів на 260000 осіб; постійної інвалідності; на 95000 менше смертей на рік [108].

Щороку в країнах ЄС пацієнти зазнають травм у результаті медичних помилок. Іноді це вина окремих чи кількох медичних працівників, але найчастіше винні організаційні чи системні збої. Неможливо повністю викорінити травми та смерть унаслідок небезпечного медичного обслуговування. Проте особи, відповідальні за надання медичної допомоги у всіх країнах, можуть зробити кроки для зниження людського та економічного тягаря несприятливих подій у всіх закладах охорони здоров'я. Безпека пацієнтів - це 
сфера охорони здоров'я, в якій економії можна досягти за рахунок підходу європейського співтовариства до вирішення проблем [109-111]. Винесення вироків, вважають Robson M., Maskill J., Brookbanks W., демонструють, що закон досить складний, щоб відрізнити некваліфіковану діяльність від необережної діяльності [112].

Комерціалізація системи правовідносин «лікар-пацієнт-фармацевт» впливає на якість медичної практики та доступність ліків для пацієнтів [113]. 3 одного боку, можуть бути несприятливі результати лікування, з другого боку, пацієнт підозрює недбалість як причину своїх страждань. Зростає тенденція до судових розглядів 3 боку незадоволених пацієнтів. Медична професія підпорядковується положенням Закону захисту прав споживачів 1986 р., у пацієнтів є простий спосіб судового розгляду. Серед лікарів має бути правова поінформованість, яка допоможе їм захистити свою справу у разі звинувачення у медичній недбалості (недбалості з боку лікаря) 3 подальшим кримінальним переслідуванням. У таких випадках необхідно проводити юридичну опіку 3 розширенням системи правовідносин «лікар-пацієнт-фармацевт-адвокат». Організаційно-правова процедура юридичної опіки включає можливість скористатися послугами адвоката з медичного та фармацевтичного права: лікар, лікарня, пацієнт, фармацевт мають право скористатися послугами адвоката для представлення їхніх інтересів; своєчасна підготовка та подача письмових заяв, афідевіту та всіх інших необхідних документів; важливо належним чином вести документообіг (історію хвороби, призначення ліків, письмові показання всіх лікарів, фармацевтів, рентгенівські знімки, результати лабораторних аналізів та ін.), які нададуть величезну допомогу у підтвердженні заяви лікаря; наявність судово-експертних висновків (чи кваліфікована та незалежна оцінка медичним, фармацевтичним фахівцем); письмові свідчення експертів, що підтверджені даними медичних, фармацевтичних наукових джерел; дані судової практики за темою розгляду (правові преценденти); використання захисту в прокуратурі, поліції та суді [113-116].

У причинно-наслідкових зв’язках некваліфікованої медичної допомоги (лікарських помилок) пацієнтам та розвитком ковідних, лонгковідних та постковідних захворювань під час пандемії COVID-19 важливе значення має безперервний професійний розвиток (БПР) фахівців сфери охорони здоров'я. Про актуальність розвитку медичного та фармацевтичного права відмічають Бабкіна О.П., Варуха К.В. [117]. Дистанційне навчання є однією з новітніх та важливих форм БПР та важливим заходом дотримання протиепідеміологічних заходів. Усі онлайн тематичні цикли інтернатури, стажування, спеціалізації та тематичного удосконалення включають питання стосовно COVID-19, світових тенденцій БПР; реформи системи підготовки медичних кадрів; сучасних технологій у системі підготовки медичних і фармацевтичних кадрів; сучасних інформаційних технологій у медичній освіті; віртуалізації освіти; психологічних проблем; збереження здоров'я соціуму; етико-правових проблем і пріоритетів розвитку медичної та фармацевтичної освіти; правових та етичних аспектів реформування системи охорони здоров'я; розвитку галузі охорони здоров'я в 
контексті правової системи України [118]. Кафедри факультетів післядипломної освіти повинні забезпечити інформаційну платформу та організувати дистанційне навчання для надання якісних освітніх послуг, впроваджуючи інноваційні педагогічні системи відповідно до вимог фармацевтичного ринку праці, забезпечуючи таким чином ефективну післядипломну підготовку слухачів циклів за даними доказової медицини і реальної практики профілактики і лікування COVID-19 [119]. Так, навчаючись на циклах тематичного удосконалення 3 ортопедичної стоматології, лікарі стоматологи-ортопеди отримують новітню інформацію, якнайглибшу і найширшу, з максимальним оволодінням практичними навичками для надання кваліфікованої та спеціалізованої допомоги. Знання сучасних методів діагностики, лікування та профілактики основних стоматологічних захворювань, дозволить підняти якість надання стоматологічної допомоги при проведенні підготовки, планування та виготовлення конструкцій зубних протезів 3 використанням актуальних методик. Отримують необхідну кількість балів БПР, оновлюють та поглиблюють професійні знання, уміння, практичні навички, ознайомлюються з основними досягненнями в галузі ортопедичної стоматології, отримують новітню сучасну інформацію, необхідну для проведення самостійної роботи в медичних закладах при виконанні певного виду втручань [120]. У сучасних умовах масивного впровадження інформаційних технологій, а також ураховуючи вплив пандемії коронавірусу, важливим стає адекватне змінення педагогічної стратегії передавання знань при БПР лікарів і провізорів. Пропонується впровадження технології метаперенесення знань, що складається 34 елементів: метамодульної (метапакетної) схеми передавання знань для формування компетентностей; оптимальної комбінації дистанційного навчання 3 отриманням знань із експертних систем; стратегії синергетичного поєднання декларативних i процедурних знань у процесі навчання; створення системи моніторингу рівня знань [121].

Міністерство охорони здоров'я України визначило правила професійного медичного стажування лікаря за межами місця працевлаштування для підвищення кваліфікації і зарахування балів БПР. Подібні стажування мають великий попит серед української спільноти лікарів, оскільки дозволяють набути нових знань і важливих професійних навичок. Наказом МОЗ від 18.08.2021 №1751 «Про внесення змін до наказу Міністерства охорони здоров’я України від 22 липня 1993 року №166» затверджені Положення про професійне медичне стажування за межами закладу, де працює працівник, а також Положення про деякі заходи БПР медичних та фармацевтичних працівників. Зокрема встановлюються чіткі правила для програми і бази стажування, його тривалості та оцінювання за його результатами. Окрім цього, наказ передбачає: осучаснені умови проведення циклів тематичного удосконалення та іспиту за результатами їх завершення; оновлені правила проходження циклів спеціалізації та атестації для отримання або підтвердження звання «лікар-спеціаліст»; порядок навчання на симуляційних тренінгах або тренінгах з опанування практичними навичками. Паралельно 3 цим були скасовані застарілі Положення про факультет 
удосконалення лікарів (провізорів) при вищих медичних i фармацевтичних навчальних закладах; про підвищення кваліфікації лікарів (провізорів) на курсах інформації і стажування; про державний інститут удосконалення лікарів (провізорів). Оновлена правова база дозволить переорієнтувати заклади вищої (післядипломної) освіти на проведення сучасних заходів БПР і забезпечення лікарів якісною освітою на післядипломному рівні [122].

Разом $з$ тим, велике значення має вивчення досвіду країн, що входять до ОЕСР, які ефективно реформували сферу охорони здоров'я, що розташовані поблизу України, наприклад Естонії [123]. Електронна охорона здоров'я Естонії - одна 3 найскладніших у світі. Цифрова система охорони здоров'я Естонії діє 3 2008 р., охоплюючи всі медичні установи країни та кожного громадянина. Країна, населення якої становить лише 1,3 мільйона осіб, вважається лідером електронного управління, особливо у сфері охорони здоров'я. Кожен громадянин має пластикову картку з чіпом - ID card. Він використовується для отримання інформації від державних служб, записок, сплати податків, запису на прийом до лікаря та отримання квитанцій. Плани з оцифровки Естонії висувалися ще 2000 p., СС виділив країні фінансування у 2005 р., а 32008 р. електронна система набула чинності. Приватні постачальники медичних послуг, державні клініки та аптеки були зобов'язані синхронізувати свої електронні платформи із загальнонаціональною медичною системою протягом 2008-2009 років. У 2018 р. було зареєстровано 1163 лікувальні заклади та 34,5 млн медичних документів, 19,4 млн медичних карт та 95 млн діагностичних висновків. Нова система створила повністю прозорі механізми фінансування та надання медичних послуг, які сьогодні доступні для кожного громадянина. Консультанти Світового банку 3 питань електронної охорони здоров'я, стверджують, що уряду доводилося змінювати та доповнювати законодавчі акти близько 16 разів, щоб отримати чітке уявлення про управління системою електронної охорони здоров'я. Саме правове регулювання та стандартизація даних допомогли зробити систему максимально прозорою, захищеною та ефективною.

Як працює інтегрована цифрова система в медицині Естонії? Система електронної охорони здоров'я Естонії має свої особливості, які дозволяють вирішувати практично всі медичні питання. Наприклад, громадяни отримують електронну медичну картку за ідентифікатором: це дозволяє їм переглядати інформацію про стан здоров'я у системі. Доступ до бази даних можна отримати через портали eesti.ee aбо digilugu.ee. У єдиному державному реєстрі охорони здоров'я зберігаються всі зустрічі з пацієнтами, встановлені діагнози, квитанції, зображення та хронічні захворювання. За бажанням можна додати дані 3 мобільних програм, таких як монітори серцевого ритму або артеріального тиску. Дорослий пацієнт також може відстежувати медичну інформацію про своїх неповнолітніх дітей. Інтегрована цифрова медична система в Естонії: автоматизує всі аспекти медичної діяльності у країні; фіксує повну інформацію про пацієнта від дня народження до смерті; заснована на надійній архітектурі, повністю безпечна; перевірена часом у національному масштабі. Важливо те, що платформа для обміну даними захищена від злому: дані пацієнта доступні тільки 
лікарю та громадянину по ідентифікатору або мобільному ідентифікатору. Також мешканці міста можуть побачити історію поглядів лікарів. Загальна електронна історія хвороби, результати аналізів та зображення протягом багатьох років дають повну картину стану здоров'я та допомагають фахівцеві найближчим часом поставити діагноз та призначити ефективніше лікування. Наприклад, у разі доставки в лікарню тяжкохворого пацієнта, медичний персонал може переглянути дані про його стан здоров'я, включаючи алергію на певні ліки та хронічні захворювання. В Естонії кожен громадянин може записатися на прийом до лікаря через Інтернет. Процес неформальний, без черг. Пацієнти отримують електронні квитанції та приносять їх в аптеку. Ліки продаються за ID-карткою. В Естонії паперові квитанції практично не зустрінеш, 99\% їх електронні. Це скорочує бюрократію, такі документи неможливо підробити, вони легко читаються як людьми, так і розумними машинами. Історія хвороби постійно оновлюється у електронному вигляді. Пацієнт може іiі прочитати та роздрукувати [123].

Правові підвалини держави України переживають непрості часи. Напевно важко згадати коли правовий нігілізм деяких категорій населення наскільки глибоко протикав до системи взаємовідносин в медичній сфері та фармацевтичній галузі. Маючи струнку i логічну систему медичного та фармацевтичного права, яка викладена у Конституції України, законах України, в тому числі і наших базових «Основи законодавства України про охорону здоров’я», «Про лікарські засоби», ми часто маємо логічні підзаконні акти Постанови Кабінету міністрів Украйни та Накази МОЗ України, але щоденно стикаємося 3 кризою виконавської дисципліни, а також впровадження та відповідальності. Навіть тоді, коли нормативно-правові акти неможливо виконати у зв'язку з різними причинами (фінансовими та ін.), ці обставини не аналізуються, не моніторяться, не узагальнюються та не виправляються, і часто замилюються новими нормативними актами, які формально покликані щось «покращити» та «вирішити». В медичній сфері та фармацевтичному секторі економіки України є три надважливі проблеми, які можливо вирішити за допомогою нормативно-правових інструментів: доступність, якість та безпека медичної допомоги та фармацевтичного забезпечення обігу ліків [124].

Висновки. Проведено мультидисциплінарне дослідження щодо вивчення судово-фармацевтичних ризиків та встановлення причинно-наслідкових зв'язків некваліфікованої медичної допомоги (лікарських помилок) пацієнтам та розвитку захворювань під час пандемії COVID-19. Обгрунтовано, що в умовах пандемії коронавірусної хвороби мультидисциплінарні дослідження у сфері охорони здоров'я об'єднують міждисциплінарні зв'язки вчених усього світу 3 медицини, фармації, права, економіки щодо належної медичної практики, фармацевтичного забезпечення та доступності лікарських засобів клінікофармакологічних, класифікаційно-правових та номенклатурно-правових груп для всіх контингентів пацієнтів. Зазначено на прикладах iз судовофармацевтичної практики, що некваліфікована медична допомога (медичні або лікарські помилки) може приводити до різного ступеню тяжкості розладів 
здоров'я, неналежне виконання професійних обов'язків медичним або фармацевтичним працівником містить у своєму змісті судово-фармацевтичні ризики щодо неналежного забезпечення лікарськими засобами, у кінцевому результаті приводить до правопорушень у сфері охорони здоров'я. Доведено, що причинно-наслідкові зв'язки прослідковуються в умовах пандемії коронавірусної інфекції на тлі ковідних, лонгковідних та постковідних розладах здоров'я. Зазначено, що пандемія на COVID-19 та їі наслідки мають 3 характерні характеристики травмуючих подій: непередбачуваність, неконтрольованість, загроза смерті або серйозної травми. Вивчено досвід США, Франції, Ізраїлю, Китаю, країн ОЕСР на прикладі Естонії щодо організації системи охорони здоров'я під час пандемії COVID-19. Показано, що комерціоналізація системи правовідносин «лікар-пацієнт-фармацевт-адвокат» впливає на якість медичної практики та доступність ліків для пацієнтів. Акцентовано увагу на те, що у причинно-наслідкових зв'язках некваліфікованої медичної допомоги (лікарських помилок) пацієнтам та розвитком ковідних, лонгковідних та постковідних захворювань під час пандемії COVID-19 важливе значення має безперервний професійний розвиток фахівців сфери охорони здоров'я. Зазначено про перспективність використання досвіду Естонії з цифрової системи охорони здоров'я, яка охоплює всі медичні установи країни та кожного громадянина.

Конфлікт інтересів. Автори засвідчують, що не мають конфлікту інтересів.

\section{Література.}

1. Shapovalova V.A., Zbrozhek S.I., Shapovalov V.V. et al. Coronavirus disease pandemia 2019: growth of epidemic dangers. Acta scientific pharmaceutical sciences. 2020. Vol. 4. Iss. 7. P. 61-68. URL: https://www.actascientific.com/ASPS/ASPS-040559.php.

2. Shapovalov V. (Jr.), Zbrozhek S., Gudzenko A. et al. Organizational and legal analysis of the pharmaceutical provision for the most common diseases of society. International Journal of Pharmaceutical Sciences Review and Research. 2018. Vol. 51. N. 1. P. 118-124. URL: http://globalresearchonline.net/journalcontents/v511/18.pdf.

3. Chuiev Y., Shapovalova V. Interdisciplinary pharmacoeconomic study of pharmacotherapy of cupping of drunk forms of alcohol dependence: clinical and pharmacological, organizational, legal and marketing experiment. SSP Modern Pharmacy and Medicine. 2021. Vol. 1. N. 2. P. 1-12. URL: https://doi.org/10.53933/sspmpm.v1i2.24.

4. Zbrozgek S. Reform of the healthcare system as a basis for streamlining the organization of circulation and availability of medicines for patients in the context of the COVID-19 pandemic. SSP Modern Pharmacy and Medicine. 2021. Vol. 1. No. 2. P. 1-32. URL: https://doi.org/10.53933/sspmpm.v1i2.31.

5. Hayduchok I. Pharmacotherapy of systemic autoimmune diseases in conditions of the COVID-19 pandemic: innovative experimental study. Science Review. 2021. Vol. 3. No. 38. P. 1-7. DOI: 10.31435/rsglobal_sr/30072021/7619. 
6. Shapovalova V.A., Zbrozhek S.I., Shapovalov V.V. et al. Forensic pharmacy: some risk factors in the formation of addictive health disorders. Acta Scientific Pharmaceutical Science. 2021. V. 4. Iss. 1. P. 7-12. DOI: 10.3180/ASPS.2020.05.0651.

7. Shapovalova V.A., Zbrozhek S.I., Shapovalov V.V. (Jr.) et al. Forensic and pharmaceutical study of causal relationships between social and medical risk factors in the formation of addictive health disorders. Health of Society. 2020. Is. 9.No. 6. P. 236242. DOI: https://doi.org/10.22141/2306-2436.9.6.2020.226954.

8. Halatsan O.V., Shapovalova V.O., Shapovalov V.V. et al. Farmatsevtychne pravo v derzhavnii systemi minimizatsii sudovo-farmatsevtychnykh ryzykiv pry obihu likarskykh zasobiv u silskii mistsevosti. Ukr. visnyk psykhonvrolohii. 2013. T. 21, Vyp. 2 (75). - S. 96-100. URL: https://uvnpn.com.ua/sq.

9. Hayduchok I., Shapovalov V. Forensic Pharmacy and Medicine: Risks for Pharmacotherapy of Addiction and Countering of Illegal Circulation of Psychoactive Substances in the COVID-19 Pandemic. SSP Modern Pharmacy and Medicine. 1(2), 1-28. URL: https://doi.org/10.53933/sspmpm.v1i2.32.

10. Shapovalov V.V., Gudzenko A.A., Shapovalova V.A. et al. Forensic and pharmaceutical analysis of addictive morbidity because of the use of psychoactive substances in Ukraine. Klin.inform.telemed. 2020. Vol. 15. Iss. 16. P. 125-128. URL: https://doi.org/10.31071/kit2020.16.02.

11. Shapovalov V.V. Forensic and pharmaceutical study of abuse and developing the principles of reducing the demand for psychoactive substances of different classification and regulatory groups. Farmatsevtychnyi zhurnal. 2014. N. 2. P. 39-47. 12. Shapovalov V. (Jr.), Gudzenko A., Shapovalova V. at. el. Forensic and pharmaceutical study of the presence of a causal link between the degree of alcohol abuse and qualification level of the respondents. Pharmacia. 2017. Vol. 66. N. 3. R. 31-39. URL: http://bsphs.org/wp-content/uploads/2017/11/Shapovalov.pdf.

13. Shapovalov (mol.) V.V., Shapovalov V.V., Shapovalova V.O., Rohozhnikova O.V. Sudovo-farmatsevtychni ryzyky: nenalezhne vykonannia profesiinykh oboviazkiv medychnym abo farmatsevtychnym pratsivnykom, shcho zavazhaie zabezpechenniu likarskymy zasobamy pilhovoho kontynhentu na osnovi farmatsevtychnoho prava. Teoriia i praktyka pravoznavstva. 2014. No. 2(6). P. 1-19. 14. Shapovalov V.V. (Jr.), Shapovalova V.A., Shapovalov V.V. Development of forensic and pharmaceutical researches within the organization of pharmaceutical business, drug technology and pharmaceutical law in Ukraine concerning the turnover of controlled drugs and substances. Health of Society. 2021. Vol. 10. N. 3. P. 98-106. DOI: https://doi.org/10.22141/2306-2436.10.3.2021.246351.

15. Shapovalova V.A., Shapovalov V.V., Shapovalov V.V. et al. Forensic and pharmaceutical assessment of polydrug addiction at combined use of psychoactive substances. Likarska sprava. 2018. N. 1-2 (1146). P. 171-177. DOI: 10.31640/JVD.12.2018(29).

16. Vasina Yu.V., Shapovalov V.V., Shapovalova V. O., Kovalova K. I. Sudovofarmatsevtychni aspekty porushen pravyl obihu psykhoaktyvnykh likarskykh zasobiv 
u zakladakh okhorony zdorovia. Ukr. visnyk psykhonevrolohii. 2015. T. 23, Vyp. 1 (82). S. 123-127. URL: https://uvnpn.com.ua/.

17. Shapovalov V.V., Shapovalov V.V. (Jr.), Shapovalova V.A. et al. The study of medicines with ephedrine circulation in the Russian Federation and in the Ukraine from the position of forensic pharmacy. Belgorod National Research University. 2017. No. 12 (261), Is. 38. P. 130-140. URL: http://dspace.bsu.edu.ru/handle/123456789/23850. 18. Shapovalov V. (Jr.), Gudzenko A., Komar L. at. el. Concerning the importance of forensic and pharmaceutical researches to improve patients accessibility to medicines. Pharmacia. 2017. Vol. 65. N. 2. P. 23-29. URL: http://bsphs.org/wpcontent/uploads/2017/07/Shapovalov.pdf.

19. Shapovalov (Jr.) V., Gudzenko A., Shapovalova V.et al. Forensic and pharmaceutical analysis of addictive morbidity because of the use of narcotic psychoactive substances in Ukraine (retrospective aspect). International Journal of Pharmaceutical Sciences and Research. 2018. Vol. 3; Is. 3. P. 22-25. URL: http://www.pharmacyjournal.net/archives/2018/vol3/issue3.

20. Gudzenko A., Shapovalov V., Shapovalov V., Shapovalova V. Forensic pharmacy: analysis of complaints about the pharmaceutical provision for privileged categories of patients in Ukraine (experimental research). Science Review. 2021. V. 2. Iss. 37. P. 1-6. DOI: https://doi.org/10.31435/rsglbal_sr/30042021/7517.

21. Shapovalov V.V. (Jr.), Shapovalov V.V., Shapovalova V.A. et al. Forensic pharmacy in the state concept of combating drug addiction among the population of Ukraine and Russia to increase the availability of narcotic analgesics. Belgorod National Research University. 2015. T. 1. No. 1. P. 30-50. URL: http://dspace.bsu.edu.ru/handle/123456789/42659.

22. Criminal Code of Ukraine as amended and supplemented as of November 20, 2021. 2001. Verkovna Rada of Ukraine. URL: https://zakon.rada.gov.ua/laws/show/2341-14\#Text.

23. COVID pandemic fuelling major increase in drug use worldwide: UN report. United Nations. URL: https://news.un.org/en/story/2021/06/1094672.

24. Operatyvna informatsiia pro poshyrennia ta profilaktyku COVID-19. MOZ Ukrainy. 31.10.2021. URL:https://moz.gov.ua/article/news/operativna-informacijapro-poshirennja-koronavirusnoi-infekcii-2019-cov19.

25. Kuryshko D. Liashko: busterna doza bude $\mathrm{z}$ sichnia, a nova khvylia kovid $-\mathrm{v}$ kintsi zymy. BBC News Ukraine. 30.11.2021. URL: https://www.bbc.com/ukrainian/features-59473820.

26. Novyny Ukrainy: Viktor Liashko zaiavyv, shcho tretia busterna doza bude dostupna ne ranishe sichnia. TSN.UA. 01.12.2021. URL:https://tsn.ua/video/videonovini/novini-ukrayini-viktor-lyashko-zayaviv-scho-tretya-busterna-doza-budedostupna-ne-ranishe-sichnya.html.

27. WHO designates new COVID strain Omicron as 'variant of concern. Gur Times. URL: https://gurtimes.com/business/who-designates-new-covid-strain-omicron-asvariant-of-concern/. 
28. WHO designates new COVID strain Omicron as 'variant of concern. Aljazeera. URL: https://www.aljazeera.com/news/2021/11/26/who-designates-new-covid-strainomicron-variant-of-concern.

29. CDC Expands Eligibility for COVID-19 Booster Shots to All Adults. CDC. 19.11.2021.

URL:https://www.cdc.gov/media/releases/2021/s1119-boostershots.html.

30. Comirnaty and Spikevax: EMA recommendations on extra doses and boosters. EMA. 10.04.2021. URL:https://www.ema.europa.eu/en/news/comirnaty-spikevaxema-recommendations-extra-doses-boosters.

31. Duqueroy V. Should Everyone Get a COVID-19 Vaccine Booster? Medscape. November 25, 2021. URL:https://www.medscape.com/viewarticle/963683.

32. Busterne shcheplennia: chomu vono duzhe vazhlyve, popry te, shcho vaktsynovanyi Izrail prodovzhuie khvority. TSN.UA. 03.12.2021. URL: https://tsn.ua/svit/busterne-scheplennya-chomu-vono-duzhe-vazhlive-popri-te-schovakcinovaniy-izrayil-prodovzhuye-hvoriti-1922848.html.

33. Omicron Spreading in U.S.; Gilead Recalls Vials: Virus Update. Bloomberg News. 03.12.2021. URL:https://www.bloomberg.com/news/articles/2021-1203/omicron-in-eight-u-s-states-south-africa-surges-virus-update.

34. «Third dose of the vaccine is extremely efficient» Israeli study: COVID booster shots $92 \%$ effective at preventing serious illness. The Times of Israel. 30.10.2021. URL: https://www.timesofisrael.com/israeli-study-covid-booster-shots-92-effectiveat-preventing-serious-illness/.

35. Barda N., Dagan N., Cohen C. et. al. Effectiveness of a third dose of the bnt162b2 mrna COVID-19 vaccine for preventing severe outcomes in Israel: an observational stugy. The Lancet. 04.12.2021. Vol. 398. Iss. 10316. P. 2093-2100. URL:https://www.thelancet.com/journals/lancet/article/PIIS0140-6736(21)022492/fulltext.

36. Barbash G. Half of serious COVID-19 cases fully vaccinated. Arutz Sheva. 08.07.2021. URL:https://www.israelnationalnews.com/News/News.aspx/309494.

37. Song W. China's global engagement to fight the novel coronavirus pandemic. Global Health Research and Policy. 2020. Vol. 5. N. 44. URL:https://ghrp.biomedcentral.com/articles/10.1186/s41256-020-00172-1/.

38. Qiu J., Shen B., Zhao M. et al. A nationwide survey of psychological distress among Chinese people in the COVID-19 epidemic: implications and policy recommendations. Gen Psychiatry. 2020. URL:https://doi.org/10.1136/gpsych-2020100213.

39. Li H., Hu M., Liu S. The need to improve the laws and regulations relevant to the outbreak of COVID-19: what might be learned from China? Viewpoints. 2020. N. 10 (1). P. 1-4. URL:https://www.ncbi.nlm.nih.gov/pmc/articles/PMC7182299/.

40. Tian H., Liu Y., Li Y. et al. An investigation of transmission control measures during the first 50 days of the COVID-19 epidemic in China. Science. 2020. Vol. 368. N. 6491. P. 638-642. URL:https://pubmed.ncbi.nlm.nih.gov/32234804/. 
41. Wang Y., Pan X., Bai Y. The Experience of patients with COVID-19 in China: an interpretative phenomenological analysis. PRBM. 28.06.2021.Vol.2021. N.14. P. 877-887.DOI: https://doi.org/10.2147/PRBM.S310266.

42. VOOZ nazvala «duzhe vysokym» zahalnyi hlobalnyi ryzyk vid novoho shtamu koronavirusu. Radio Svoboda.

30.11.2021. URL: https://www.radiosvoboda.org/a/news-omikron-vooz-ryzyky/31586271.html.

43. Bratushchyk-Khoma M. Duzhe vysokyi ryzyk spleskiv: u yakykh krainakh vyiavyly Omicron ta chy efektyvni vid noho vaktsyny. Ukr. tyzhden. 30.11.2021. URL: https://tyzhden.ua/Pandemic/253756.

44. Kuznetsova I. Pro oboviazkovu vaktsynatsiiu, tretiu dozu, COVID-shakhraistvo i zarplaty medykiv. Interviu ministra Liashka. Radio Svoboda. 16.10.2021. URL: https://www.radiosvoboda.org/a/intervyu-z-ministrom-okhorony-zdorovya-viktoromlyashkom/31509945.html.

45. VOOZ nazvala «duzhe vysokym» zahalnyi hlobalnyi ryzyk vid novoho shtamu koronavirusu. Radio Svoboda. 30.11.2021. URL: https://www.radiosvoboda.org/a/news-omikron-vooz-ryzyky/31586271.html.

46. Voronenko Yu.V. Bezperervnyi profesiinyi rozvytok likariv ta provizoriv $\mathrm{v}$ umovakh reformuvannia systemy okhorony zdorovia (9 zhovtnia 2020 roku). MOZ Ukrainy, Natsionalna medychna akademiia pisliadyplomnoi osvity imeni P. L. $\begin{array}{lllll}\text { Shupyka. } & \text { Kyiv. } & 2020 . & \text { S. } & 24-25 \\ \text { URL: }\end{array}$ https://nmapo.edu.ua/zagruzka2/CPD_conference_NMAPO_2020.

47. Shapovalov V. V., Shapovalov V. V., Shapovalova V. A., Omelchenko V. O. Vyvchennia mizhdystsyplinarnykh zviazkiv kryminalno-pravovykh ta sudovofarmatsevtychnykh norm u systemi obihu likarskykh zasobiv. Teoriia $i$ praktyka pravoznavstva. 2017. Vyp. 1 (11). 9s. URL: https://dspace.nlu.edu.ua/bitstream/123456789/16367/1/11.

48. Shapovalov Valentyn V., Shapovalov V.V., Shapovalova V.O., Kulikova O.V. Orhanizatsiia zabezpechennia antypsykhotychnymy likarskymy zasobamy na zasadakh farmatsevtychnoho prava i sudovoi farmatsii. Ukr. visnyk psykhonvrolohii. 2016. T. 24. Vyp. 1 (86). S. 138-144. URL: http://www.psychiatry.ua/uvp/.

49. Shapovalov V.V., Shapovalov V.V. (ml.), Shapovalova V.A. Farmatsevtycheskoe y medytsynskoe pravo: uch. posob. (seryia: Farmatsevtycheskoe pravo). [1-e yzd.]. Kh.: Yzd-vo «Skorpyon», 2011. 208 s.

50. Radionova V.A., Shapovalov V.V. (ml.), Shapovalova V.A. et al. Sudebnofarmatsevtycheskoe yzuchenye problemy zhenskoi narkomanii: prichinnosledstvennie sviazi oborota psykhoaktivnykh veshchestv, zabolevaemosty u narkoprestupnosti. Belgorod National Research University. 2015. No. 4 (201). V. 29. S.124-130. URL: $\quad$ https://www.bsu.edu.ru/bsu/science/public/bsusciencejournal/detail.php?IBLOCK_ID=106\&SECTION_ID=572\&ELEMENT_ID= 326706.

51. Shapovalov V.V. (Jr.), Shapovalova V.A., Shapovalov V.V. et al. Forensic and pharmaceutical status of the determination of depending from cannabinoids (F12). European Applied Sciences. 2013. Vol. 2. N. 9. P. 146-149. 
52. Shapovalov (Jr.) V.V., Shapovalova V.V., Shapovalov V.V. et al. Comparative analysis of availability of the medicines for privileged categories of citizens suffering from diabetes mellitus in the Russian Federation and Ukraine based on the pharmaceutical law. Annals of Mechnikov institute. 2015. N. 1. P. 14-20. URL: http://nbuv.gov.ua/jpdf/ami_2015_1_4.pdf.

53. Shapovalova V.O., Shapovalov V.V., Osyntseva A.O. Vyznachennia dostupnosti likarskykh zasobiv dlia farmakoterapii alkoholnoi ta pyvnoi adyktsii z pozytsii farmatsevtychnoho i medychnoho prava ta sudovoi farmatsii. Klinichna farmatsiia, farmakoterapiia ta medychna standartyzatsiia. 2014. No. 3-4. S. 39-46.

54. Shapovalova V.O., Vasina Yu.V., Shapovalov V.V. Vyvchennia systemy obihu ekstemporalnykh likarskykh zasobiv v Ukraini na zasadakh farmatsevtychnoho prava Farmatsevtychnyi zhurnal. 2016. No. 1. S.77-85 URL: http://nbuv.gov.ua/UJRN/pharmazh_2016_1_15.

55. Shapovalov V.V., Shapovalova V.A., Shapovalov (Jr.) et al. The problem of turnover of the psychoactive substance alcohol: abuse, consequences, countermeasures. Research result. 2014. Vol. 1. N.2 (2). P. 45-51. URL: http://www.belsu-research-result.ru/images/issue2/pharmacy/pharmacy.pdf.

56. Shapovalov V.V. (ml.), Shapovalov V.V. Shapovalova V.A. et al. Sravnitelnyi analyz orhanyzatsyy farmatsevtycheskoi pomoshchi v Rossii, Ukraine y Belorussii v obespechenii lhotnykh katehoriy naselenyia. Belgorod National Research University. 2015. No. 10 (207). V. 30. S. 226-238. URL: http://dspace.bsu.edu.ru/handle/123456789/23850.

57. Shapovalov V.V. (ml.), Shapovalova V.A. Shapovalova V.V. et al. Izuchenie osobennostei oborota lekarstvennykh sredstv s efedrinom v Rossii i Ukraine s pozitsii sudebnoi farmatsii. Belgorod National Research University. 2015. No. 22 (219). V. 32. S. 175-180. URL: http://dspace.bsu.edu.ru/handle/123456789/23850.

58. Shapovalov V.V. (Jr.), Zbrozhek S.I., Shapovalova V.O. et al. Organizational and legal evaluation of availability of medicines circulation for cancer patients. Pharmacia. 2018. Vol. 65. N. 2. P. 17-22. URL: http://bsphs.org/?magasine=organizational-and-legal-evaluation-of-availability-ofmedicines-circulation-for-cancer-patients.

59. Shapovalov V.V. (Jr.), Shapovalova V.A., Shapovalov V.V. Forensic and pharmaceutical research on the impact of drugs on the safety, life and health of road users within the organization of pharmaceutical business, drug technology, pharmaceutical and medical law in Ukraine. Health of Society. 2021. Vol. 10. N. 4. R. 127-132. DOI: https://doi.org/10.22141/2306-2436.10.4.2021.246355.

60. Shapovalova V.A., Shapovalov V.V., Riazantseva N.N. et al. Klinikofarmatsevticheskaya bezopasnost bezretsepturnykh protyvoiazvennykh lekarstvennykh sredstv s pozytsii dokazatelnoi meditsini i farmatsii. Farmatsyia Kazakhstana. 2015. No. 1 (164). S. 32-39. URL: https://www.ndda.kz/upload/dari.kz/Zhurnal/pharm_01_2015sait.

61. Shapovalov V.V., Shapovalova V.O. Modern state support drug patients in rural areas: analysis of complaints of citizens on principles of medical and pharmaceutical law. E-Journal: Research Bulletin SWorld «Modern scientific research and their 
practical application». 2013. R.93-96. URL: https://www.elibrary.ru/item.asp?id=28873229.

62. Petrenko V.O., Shapovalova V.O., Shapovalov V.V. Sudova farmatsiia: vyvchennia osoblyvostei zlovzhyvannia psykhoaktyvnymy rechovynamy riznykh klasyfikatsiino-pravovykh hrup sered zhinok. UVP. 2010. T. 18. Vyp. 4 (65). S. 98100. URL: https://uvnpn.com.ua/.

63. Shapovalova V., Shapovalov V., Shapovalov V. et al. Experience of the department of medical and pharmaceutical law, general and clinical pharmacy of the Kharkiv medical academy of postgraduate education concerning the educational process during the quarantine period caused by COVID-19. Actual Problems of Medicine and Pharmacy. 2021. Vol. 2. N. 2. P. 1-20. URL: https://doi.org/10.52914/apmp.v2i2.33.

64. Shapovalova V.A., Sosin Y.K., Shapovalova V.V. et al. Farmatsevtycheskoe pravo v narkolohyy. Kharkov: Fakt, 2004. 800 s.

65. Hubskyi Yu.I., Shapovalova V.A., Kutko I.I. et al. Lekarstvennie sredstva v psykhofarmakologii. K.: "Zdorovia", Kharkov: "Torsing”. 1997. 288 s.

66. Shapovalova V.A., Danylenko V.S., Shevchenko S.Y. et al. Lekarstvennie sredstva v klinicheskoi khirurgii. Kh.: "Torsing". 1998. $605 \mathrm{~s}$.

67. Shapovalova V.A., Shapovalov V.V. Spravochnyk po pravovoi y sudebnoi farmatsyy. Kharkov: «Torsynh». 1997. $656 \mathrm{~s}$.

68. Shapovalova V.A., Danylenko V.S., Shapovalov V.V. et al. Lekarstvennie sredstva, otpuskaemye bez retsepta vracha. Kharkov: "Torsing". 1988. $528 \mathrm{~s}$.

69. Shapovalova V.A., Shapovalov V.V., Vyrva E.E. et al. Farmatsevticheskoe pravo v ginekologii. Kharkov: Fakt. $288 \mathrm{~s}$.

70. Shapovalova V.O., Shapovalov V.V. Pytannia normatyvnoho tlumachennia i klasyfikatsii likarskykh zasobiv yak skladovoi chastyny u haluzi pravovoho rehuliuvannia obihu sylnodiiuchykh, otruinykh i psykhotropnykh rechovyn, narkotychnykh zasobiv i prekursoriv v Ukraini. Farmakol. Visnyk. 1998. No. 4. S. 1924.

71. Shapovalov V.V. (ml.), Ryshchenko O.A., Shapovalov V.V. et al. Meditsynskoe i farmatsevticheskoe pravo: analiz kliniko-farmakolohicheskikh hrupp lekarstvennykh sredstv, primeniaemykh $\mathrm{v}$ farmakoterapii kardiologicheskikh zabolevaniy $\mathrm{v}$ ramkakh formuliarnoi systemy Rossii i Ukrainy. Belgorod National Research University. 2014. No. 24 (195). V. 28. S.137-143. URL: https://www.bsu.edu.ru/bsu/science/public/bsuscience-journal/list.php?SECTION_ID=572.

72. Ryshchenko O.O., Shapovalov V.V., Shapovalova V.O. et al. Sudovofarmatsevtychne doslidzhennia rehionalnoho rivnia zabezpechennia likarskymy zasobamy patsiientiv z neiroendokrynnymy onkolohichnymy zakhvoriuvanniamy na osnovi medychnoho ta farmatsevtychnoho prava. Farmakom. 2014. No. 3. S. 56-62. URL: http://sphu.org/wp-content/uploads/2017/01/Farmacom_3_2014.pdf.

73. Shapovalov V.V. (ml.), Shapovalov V.V., Omelchenko V.A. et al. Farmatsevticheskoe pravo: neobkhodimost povyshenyia urovnia informirovaniya vrachei i provizorov o pravilakh oborota narkotycheskikh i psikhotropnykh 
lekarstvennykh sredstv (sudebno-farmatsevticheskie aspekty). Vestnyk Tadzhykskogo natsionalnogo universiteta. 2013. No. 3 (4). S. 135-140.

74. Shapovalov Valentyn V., Shapovalov V.V., Shapovalova V.O. et al. Sudovofarmatsevtychni ryzyky: nenalezhne vykonannia profesiinykh oboviazkiv medychnym abo farmatsevtychnym pratsivnykom, shcho zavazhaie zabezpechenniu likarskymy zasobamy pilhovoho kontynhentu na osnovi farmatsevtychnoho prava. Teoriia i praktyka pravoznavstva. 2014. V. 2 (6). URL: http://tlaw.nlu.edu.ua/article/view/63579.

75. Shapovalov V.V., Shapovalova V.A., Petrenko S.L. Ispolzovanie rezultatov operativno-rozysknoi deiatelnosty otdelov po borbe $\mathrm{s}$ narkotikami $\mathrm{v}$ protsesse prepodavanyia predmeta «Pravovaia i sudebnaia farmatsiia» dlia ukreplenyia natsyonalnoi bezopasnosty. Zb. nauk. prats: "Aktualni problemy medychnoi nauky". Kh.: «Oko». 1998. S. 323-327.

76. Shapovalova V.A., Zabolotnyi V.A., Depeshko Y.T. et al. Farmatsevticheskiy analiz lekarstvennykh sredstv. Kharkov: YMP "Rubykon". 1995. $400 \mathrm{s.}$

77. Haiduchok I.H., Shapovalova V.O., Shapovalov Val. V. et al. Rezhym kontroliu antybakterialnykh likarskykh zasobiv dlia farmakoterapii koronavirusnoi khvoroby (COVID-19) u patsiientiv $\mathrm{z}$ dualnymy rozladamy: informatsiinyi lyst pro novovvedennia. Ukrmedpatentinform MOZ Ukrainy. K.: Ukrmedpatentinform MOZ Ukrainy. 2020. N. 230-2020. 6 s.

78. Hayduchok I. Pharmacotherapy of systemic vasculitis combined with cryoglobulinemic syndrome using pharmacoeconomic approaches. Global Journal of Health Science. 2021. Vol. 13. N. 7. P. 78-88. URL: https://doi.org/10.5539/gjhs.v13n7p78.

79. Roberts M. What are the Delta, Gamma, Beta and Alpha Covid variants? BBC News. URL: https://www.bbc.com/news/health-55659820.

80. Callaway E. Heavily mutated coronavirus variant puts scientists on alert. Nature. 25.11.2021. URL:https://www.nature.com/articles/d41586-021-03552-w.

81. Naidoo R., Cele S. New Coronavirus Variant a 'Serious Concern in South Africa. Bloomberg. URL: https://www.bloomberg.com/news/articles/2021-1125/who-meets-on-new-covid-19-variant-circulating-in-south-africa

82. Hayduchok I.G. Innovation approaches to pharmacotherapy of systemic autoimmune diseases in the conditions of the COVID-19 pandemic. Likarska Sprava. 2020. N. 7-8. P. 64-74. DOI: 10.31640/JVD.7-8.2020 (8).

83. Hayduchok I. Supportive pharmacotherapy for systemic autoimmune diseases with hyperimmunocomplex syndrome (experimental research). Georgian medical news. 2021. N. 9 (318). P. 159-165.

84. Hayduchok I. Pharmacotherapy of systemic autoimmune diseases in the sonvention of the COVID-19 pandemic: search for innovative technologies in the study. Acta Scientific Medical Science. 2021. Vol. 5. Iss. 9. P. 136-142. DOI: 10.31080/ASMS.2020.05.1022.

85. Hayduchok I. Pharmacotherapy of psoriasis support with antiphospholipid syndrome: ABC/VEN - analysis of anti-viral drugs. SSP Modern Pharmacy and Medicine. 2021. Vol. 1. Iss. 1. P. 1-12. DOI: https://doi.org/10.53933/sspmpm.v1i1.4. 
86. Classification of Omicron (B.1.1.529): SARS-CoV-2 Variant of Concern. WHO. 26.11.2021. URL: https://www.who.int/news/item/26-11-2021-classification-ofomicron-(b.1.1.529)-sars-cov-2-variant-of-concern/.

87. Tukhar I., Shapovalova V., Shapovalov V. et al. Pharmacological view on the problem of comorbidity in the pharmacotherapy of chronic pancreatitis. Science Review. Vol.3. N.38. P.1-5. DOI: 10.31435/rsglobal_sr/30072021/7591.

88. Tanno L.K., Chalmers R., Jacob R. at el. Global implementation of the World Health Organizations International Classification of Diseases (ICD)-11: The allergic and hypersensitivity conditions model. Allergy. 2020. N.75(9). R. 2206-2218. DOI: 10.1111/all.14468. URL: https://pubmed.ncbi.nlm.nih.gov/32578235/.

89. Poshchady ne chekaite: Venediktova oholosyla viinu pidrobnym kovidsertyfikatam. $\quad B B C$ news Ukraina. 23.10.2021. URL: https://www.bbc.com/ukrainian/news-59021302.

90. Jonathan Jarry M.Sc. Medical error is not the third leading cause of death? McGill. 27.08.2021. URL: https://www.mcgill.ca/oss/article/critical-thinkinghealth/medical-error-not-third-leading-cause-death.

91. Saks M. J., Landsman S. Use systems redesign and the law to prevent medical errors and accidents. Stat. 04.08.2021. URL: https://www.statnews.com/2021/08/04/medical-errors-accidents-ongoingpreventable-health-threat/.

92. Makary M. A, Daniel M. Medical error - the third leading cause of death in the US. BMJ. 2016. N. 353. DOI: https://doi.org/10.1136/bmj.i2139.

93. Postanova MOZ Ukrainy vid 09.05.2020 No. 19 "Pro zatverdzhennia tymchasovykh rekomendatsii shchodo orhanizatsii protyepidemichnykh zakhodiv pry nadanni stomatolohichnoi dopomohy na period karantynu u zviazku z poshyrenniam koronavirusnoi khvoroby (COVID-19)". Verkhovna Rada Ukrainy. 09.05.2020. URL: https://zakon.rada.gov.ua/rada/show/v0019488-20\#Text.

94. Sprava rivnenskoi stomatolohyni pishla do sudu. Bykvu.com. 11.03.2021. URL: https://bykvu.com/ua/bukvy/sprava-rivnenskoi-stomatologini-pishla-do-sudu/.

95. U Rivnomu pereviriaiut stomatoloha cherez travmy u ditei. Ukrainska pravda. 12.02.2021. URL: https://www.pravda.com.ua/news/2021/02/12/7283276/.

96. Viddil komunikatsii politsii Rivnenskoi oblasti. Kryminalne provadzhennia shchodo rivnenskoi stomatolohyni skeruvaly do sudu. MVS.gov.ua. 11.03.2021. URL:https://mvs.gov.ua/ua/news/39624_Kriminalne_provadzhennya_shchodo_rivne nskoi_stomatologini_skeruvali_do_sudu.htm.

97. V Zhytomyre vrach putalsia ubyt dyrektora stomatolohycheskoho tsentra. Ukrayna Krymynalnaia. 27.11.2020. URL: https://cripo.com.ua/news/crime/vzhitomire-vrach-pytalsya-ubit-direktora-stomatologicheskogo-tsentra/.

98. Vstromyv nozhytsi v oko: na Zhytomyrshchyni pidlehlyi namahavsia vbyty dyrektorku stomatolohichnoho tsentru. NV. 30.11.2020. URL: https://nnovosti.info/news/vstromiv_nozhitsi_v_oko_na_zhitomirschini_pidleglij_na magavsja_vbiti_direktorku_stomatologichnogo_tsentru_foto-55919.html.

99. Smert 2-letneho malusha v kabynete stomatoloha: pochemu sud v Maryupole opravdal vracha. Fakty Ukraina. 31.07.2021. URL: https://crime.fakty.ua/ru/381784- 
smert-2-letnego-malysha-v-kabinete-stomatologa-pochemu-sud-v-mariupoleopravdal-vracha.

100. Na Mukachivshchyni zatrymaly stomatoloha, yakyi prodavav amfetamin. Mukachevo.net. 18.10.2018. URL: http://www.mukachevo.net/ua/news/view/369220. 101. Stomatolohu z Mukachivshchyny, yakyi prodavav narkotyky, oholosyly pidozru. Mukachevo.net. 19.10.2018.

URL: http://www.mukachevo.net/ua/news/view/369238.

102. Woods R. Why did Rachel Johnston die after having all her teeth removed? $B B C$ News. 14.12.2018. URL: https://www.bbc.com/news/uk-england-hereford-worcester46522258.

103. When does malpractice become a criminal act? ReliasMedia. 01.08.2020. URL: https://www.reliasmedia.com/articles/46678-when-does-malpractice-become-acriminal-act.

104. Wang L., Wang F., Gershwin M. Human autoimmune diseases: a comprehensive update. Journal of Internal Medicine. 2015. Vol. 278. N. 4. P. 369-395. DOI: 10.1111/joim.12395.

URL:

https://onlinelibrary.wiley.com/doi/full/10.1111/joim.12395.

105. Hoffman M. What are autoimmune disorders? WebMD. 2020. URL: https://www.webmd.com/a-to-Z-guides/autoimmune-diseases.

106. Charangowda B. Dental records: an overview. J. Forensic Dent. Sci. 2010. Vol.2. N.1. P.5-10. DOI: 10.4103/0974-2948.71050.

107. General Dental Council. Standards for the dental team. 2013. 11 r. URL: https://standards.gdc-

uk.org/Assets/pdf/Standards\%20for\%20the\%20Dental\%20Team.pdf.

108. Data and statistics. WHO euro. 24.19.2021. URL: https://www.euro.who.int/en/health-topics/Health-systems/patient-safety/data-andstatistics.

109. McGill L. Patient safety: a European Union priority. Clin Med (Lond). 2009. Vol. 9. N.2. R. 136-139. DOI: 10.7861/clinmedicine.9-2-136. URL: https://pubmed.ncbi.nlm.nih.gov/19435118/.

110. Politicians postpone discussion of decriminalization of medical errors. BNN. 27.11.2019. URL: $\quad$ https://bnn-news.com/politicians-postpone-discussion-ofdecriminalization-of-medical-errors-207820.

111. Fuchsberg A. When Do Doctor Errors Become Criminal Medical Negligence? Fuchsberg. 2016. URL: https://www.fuchsberg.com/blog/medical-errors-becomecriminal-negligence.

112. Robson M., Maskill J., Brookbanks W. Doctors Are Aggrieved—Should They Be? Gross Negligence Manslaughter and the Culpable Doctor. The Journal of Criminal Law. 17.08.2020.

URL:

https://journals.sagepub.com/doi/full/10.1177/0022018320946498.

113. Pandit M.S. Medical negligence: criminal prosecution of medical professionals, importance of medical evidence: some guidelines for medical practitioners. 2009. Indian J. Urol. Vol. 25. N. 3. R. 379-383. DOI: 10.4103/0970-1591.56207. URL:https://www.ncbi.nlm.nih.gov/pmc/articles/PMC2779964/. 
114. Shapovalov V.V. Sudova farmatsiia: yurydychna opika spetsialistiv farmatsii i medytsyny u sferi protydii narkomanii i nezakonnomu obihu psykhoaktyvnykh rechovyn. Ukrainskyi visnyk psykhonevrolohii. 2011. T. 19. V. 1. S. 115-119.

115. Shapovalov V.V. Yurydychna opika v systemi pravovidnosyn «likar - patsiient - provizor» na zasadakh medychnoho i farmatsevtychnoho prava. Upravlinnia zakladom okhorony zdorovia. 2012. No. 9. S. 29-37

116. Shapovalov V.V., Sosin I.K., Kapielnikova Ye.V.. Avtorske pravo 59560, Ukraina. Yurydychna opika v systemi pravovidnosyn «likar» - «narkokhvoryi»«provizor» u prohramakh zamisnoi pidtrymuvalnoi terapii v Ukraini. No. 59997. Zaiavl. 10.03.15. Opubl. 07.05.15.

117. Babkina O.P., Varukha K.V. Do pytannia pro zapobihannia prytiahnennia farmatsevtychnykh pratsivnykiv do kryminalnoi vidpovidalnosti. Kh.: Vyd-vo NFaU. 2015. S. 25-26.

118. Diadyk O.D., Zaritska V.K., Beketova Yu K. ta in. Osoblyvosti bezperervnoho profesiinoho rozvytku likariv patolohoanatomiv $\mathrm{v}$ umovakh reformuvannia medytsyny ta pandemii Covid-19 // Bezperervnyi profesiinyi rozvytok likariv ta provizoriv v umovakh reformuvannia systemy okhorony zdorovia ( 9 zhovtnia 2020 roku). MOZ Ukrainy, Natsionalna medychna akademiia pisliadyplomnoi osvity imeni P. L. Shupyka. Kyiv: NMAPO imeni P. L. Shupyka, 2020. S. 125-127. URL: https://nmapo.edu.ua/zagruzka2/CPD_conference_NMAPO_2020.

119. Barchuk O., Zaliska O., Maksymovych N. Priorytety bezperervnoho profesiinoho rozvytku provizoriv v umovakh pandemi Covid-19 ta reformuvannia systemy okhorony zdorovia Ukrainy. Kyiv: NMAPO imeni P.L. Shupyka, 2020. S. 127128 URL: https://nmapo.edu.ua/zagruzka2/CPD_conference_NMAPO_2020.

120. Bida V. D., Doroshenko O. D., Radko V. K. ta in. Orhanizatsiia bezperervnoho profesiinoho rozvytku likariv stomatolohiv-ortopediv na kafedri ortopedychnii stomatolohii. Kyiv, NMAPO imeni P.L. Shupyka. 2020. S. 152-158. URL: https://nmapo.edu.ua/zagruzka2/CPD_conference_NMAPO_2020.

121. Mintser O., Babintseva L. Hlobalni zminy pedahohichnoi stratehii peredavannia znan pry bezperervnomu profesiinomu rozvytku likariv i provizoriv $\mathrm{v}$ umovakh pandemii. Kyiv: NMAPO imeni P.L. Shupyka, 2020. S. 33-37 URL: https://nmapo.edu.ua/zagruzka2/CPD_conference_NMAPO_2020.

122. Likari zmozhut pidvyshchuvaty kvalifikatsiiu zavdiaky profesiinomu medychnomu stazhuvanniu. MOZ Ukrainy. 15.11.2021. URL: https://moz.gov.ua/article/news/likari-zmozhut-pidvischuvati-kvalifikaciju-zavdjakiprofesijnomu-medichnomu-stazhuvannju.

123. Everything you need to know about the Estonian eHealth reform. M-Health Conference Tallinn. 27.03.2019. URL: https://tallinn.mhealth.events/en/article/vsyoo-tsifrovoy-meditsinskoy-reforme-v-estonii-97210.

124. Serdiuk V. Zvernennia prezydenta Vseukrainskoi Rady zakhystu prav ta bezpeky patsiientiv. Sait Lvivskoho medychnoho instytutu. 26.10.2021. URL: https://medinstytut.lviv.ua/zvernennya-viktora-serdyuka/. 